\title{
ABSORPTION OF SODIUM AND CALCIUM BY WHEAT SEEDLINGS ${ }^{x}$
}

\author{
HOWARD S. REED
}

(WITH ONE FIGURE)

Sea water, mammalian blood, and certain artificial solutions in which living cells are immersed are capable of continuing the life of those cells for considerable periods of time. These so-called "balanced solutions" may contain different ions which, separately, have a marked deleterious effect upon the cell, but which, when present in certain proportions, "balance" or "antagonize" each other. The result is that organisms live normally in such solutions.

There are two ways in which the mixture of ions or molecules in a balanced solution may overcome cytolytic factors: (I) by "antagonizing" each other, that is, by opposing and mutually excluding each other at the surface of the plasmatic bodies or other units of living structure; (2) by producing in the organism such a s1ate of "tolerance," that is, by producing effects on the intracellular complexes, either alone or in conjunction with each other, that the harmful effects of single ions or molecules are eliminated. Or, in other words, the antagonism of ions may be either peripheral or internal.

Until recently the majority of physiologists were inclined to the former view, a view which was clearly stated in TraubE's "sieve theory of permeability" and in OverTon's "lipoid-solubility" theory. Of the many objections to these two theories and to their various modifications, none was more cogent than that based on the fact that, even in a balanced solution, ions do slowly enter the cell. Indeed, if such were not the case, it would be impossible for the cell to obtain the salts necessary for its existence.

The objections to the former ideas of "antagonism" and "tolerance" have largely been met by a theory of antagonism pro-

${ }^{I}$ Paper 47, from the University of California, Graduate School of Tropical Agriculture and Citrus Experiment Station, Riverside, California. 
posed by Osterhout, ${ }^{2}$ which holds that the slow penetration of salts may produce effects on the cell quite different from those produced by rapid penetration, and that their action is on the life processes rather than on the manner or rate of penetration. "From this point of view we regard the slow penetration of salts in balanced solutions not as the cause but as the result of antagonism, or rather we may regard the slow penetration and the increased length of life (or growth, etc.), by which we measure antagonism, as the results of certain life processes which are directly acted on by the antagonistic substances."

OSTERHOUT found that the theory was satisfactorily supported when the penetration of certain known mixtures of $\mathrm{NaCl}$ and $\mathrm{CaCl}_{2}$ into living cells was studied. He makes, however, a seeming exception in the case of solutions of lower concentration, stating: "Below the saturation point ${ }^{3}$ the relative proportions of the salts will be of less importance than their total concentration; this is the case at low concentrations in the region of the so-called 'nutritive effects."'

Shive and Totringham, on the other hand, not to mention others, have rather definitely shown that there are certain distinctly favorable ratios in nutrient solutions of equivalent concentration.

In view of OSTERHOUT'S rather sweeping exclusion of nutrient solutions of low concentration, it seemed profitable to the writer to investigate the effect of some of OSTERHOUT's proportions in weak solutions, coupled with analyses of the plants to determine the amounts of solute taken up. It is a pleasure to acknowledge my indebtedness to Mr. J. F. BREAZEALE for the cultures and analyses upon which this work is based.

The experiments to be reported were conducted on wheat seedlings grown on disks of perforated aluminum buoyed by glass bulbs

${ }^{2}$ Osterhout, W. J. V., The penetration of balanced solutions and the theory of antagonism. Science, N.S. 44:395. 1916.

—, A dynamical theory of antagonism. Proc. Amer. Phil. Soc. 55:533. I9I6.

${ }^{3}$ The term "saturation point" as used is taken to mean the point at which the surface of a plasmatic structure is saturated with the antagonizing salts. Beyond this point an increase in their concentration in the solution produces no effect on their concentration in the surface. 
in such a way that the aluminum disk floated at the surface of the solution. Each disk was floated on about 3 liters of solution in an agate enameled pan. The seeds were germinated in a solution of the same composition as that designed for the experiment. None but sprouted seeds were used. Each disk originally held about Iooo seedlings, but careful selection brought the number down to about 200 .

In attempting to study the effect of a small amount of calcium, special precautions are necessary, owing to the abundance of calcium compounds in our environment. The seeds and apparatus used must be washed in dilute $\mathrm{HCl}$ and rinsed with distilled water of undoubted purity. The cultures must be carefully protected from dust, especially dust from plastered walls, or from cement floors, which might carry salts of calcium, since I part per million of calcium may produce distinct effects. It is necessary to work in somewhat the same way as one works with cultures of bacteria.

The antagonism of calcium and sodium has been a matter of record in connection with Osterhout's data. The case is illustrated by the cultures shown in fig. I, which show the toxic action of 4000 p.p.m. $\mathrm{NaCl}$ and the antidoting action of $\mathrm{CaSO}_{4}, \mathrm{CaO}$, and $\mathrm{Mg}\left(\mathrm{HCO}_{3}\right)_{2}$. The wheat seedlings shown in the figure were similar at the outset and grew 7 days in the respective cultures. The concentration of 4000 p.p.m. $\mathrm{NaCl}$ is about the toxic limit for wheat seedlings under these conditions, yet 30 p.p.m. of a calcium salt antagonized completely the toxicity. Magnesium bicarbonate was not so successful in overcoming the bad effects of sodium chloride.

A further illustration of the antagonistic action of calcium is shown in table I, which gives data pertaining to wheat plants grown in solutions of sodium chloride with and without the addition of $\mathrm{CaO}$. It will be seen that (I) measured by ash content and by dry weight of plants the addition of 30 p.p.m. $\mathrm{CaO}$ was beneficial to growth; (2) the amount of $\mathrm{NaCl}$ absorbed by the plants was not decreased when $\mathrm{CaO}$ was added. In the case of cultures 4 and 5 of table $\mathrm{I}$ the ratio of $\mathrm{NaCl}$ to total ash is $\mathrm{I}: \mathrm{I} .9$ where only $\mathrm{NaCl}$ was present in the solution and $\mathrm{I}: 2.3$ where both $\mathrm{NaCl}$ and $\mathrm{CaO}$ were present. From this it would seem that the calcium salt 
has not benefited the plant by excluding sodium, especially in view of the amount found in the tops, but rather has rendered it harmless within the plant.

A second set of cultures was made in which the ratios of sodium to calcium were identical with some of those employed by OsTERHout. The pure $\mathrm{NaCl}$ and $\mathrm{CaCl}_{2}$ solutions were each $0.004 \mathrm{M}$.

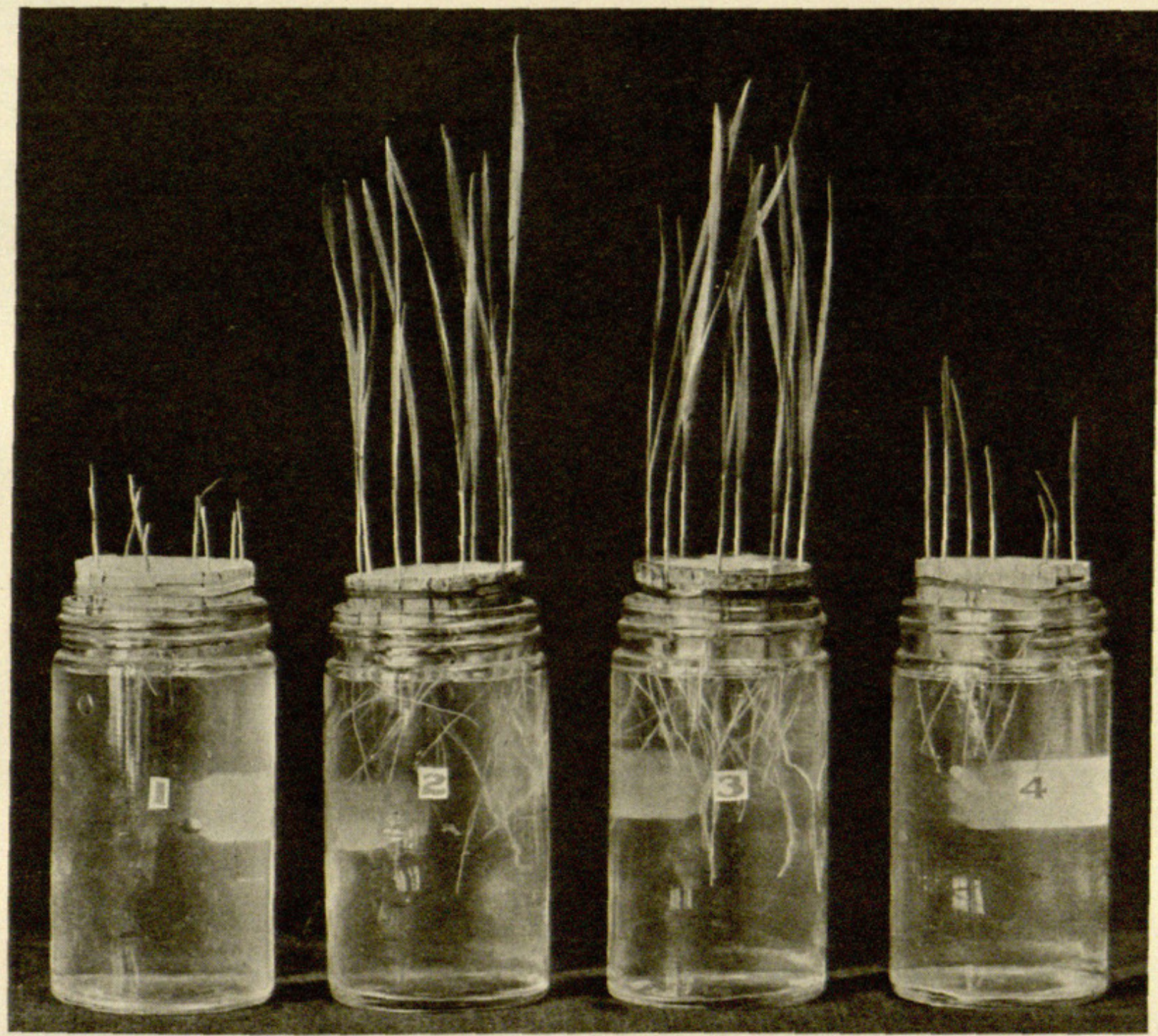

FIG. I.-Effect of calcium and magnesium salts upon toxicity of sodium chloride to wheat plants: culture solutions were jar I, 4000 p.p.m. NaCl; jar 2, 4000 p.p.m. $\mathrm{NaCl}$ plus 30 p.p.m. $\mathrm{CaSO}_{4} ;$ jar 3,4000 p.p.m. $\mathrm{NaCl}$ plus 30 p.p.m. $\mathrm{CaO}$; jar 4 , 4000 p.p.m. $\mathrm{NaCl}$ plus 30 p.p.m. $\mathrm{Mg}\left(\mathrm{HCO}_{3}\right)_{2}$.

This is much less than the concentration of $\mathrm{NaCl}$ employed in the first series, being 230 p.p.m. of $\mathrm{NaCl}$ instead of 4000 p.p.m. This series of cultures was continued for 16 days, at which time roo representative plants were withdrawn from each culture, weighed, and analyzed, giving the data shown in table II. 
It seems quite evident from these results that one of the ratios of $\mathrm{Na}: \mathrm{Ca}$ in which Osterhout found the greatest amount of antagonism was the one most favorable for growth in this series.

\section{TABLE I}

EFFECT OF CALCIUM OXIDE ON GROWTH AND ABSORPTION OF SODIUM CHLORIDE BY WHEAT PLANTS

\begin{tabular}{|c|c|c|c|c|c|c|c|c|}
\hline \multirow{2}{*}{ Plants GROWN IN } & \multirow{2}{*}{ DAYS } & \multicolumn{2}{|c|}{$\begin{array}{c}\text { ANALYSIS OF } \\
\text { IOO TOPS }\end{array}$} & \multicolumn{5}{|c|}{ ANALYSIS OF IDO ENTIRE PLANTS } \\
\hline & & Ash & $\mathrm{NaCl}$ & $\begin{array}{c}\text { Green } \\
\text { weight }\end{array}$ & $\begin{array}{c}\text { Dry } \\
\text { weight }\end{array}$ & Ash & $\mathrm{CaO}$ & $\mathrm{NaCl}$ \\
\hline 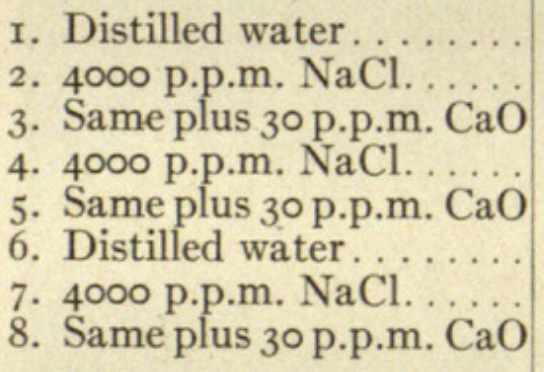 & $\begin{array}{r}8 \\
8 \\
8 \\
\text { I0 } \\
10 \\
8 \\
8 \\
8\end{array}$ & $\begin{array}{l}0.0462 \\
0.0775 \\
0.0921 \\
\cdots \cdots \\
\cdots \cdots \\
\cdots \cdots \\
\cdots \cdots\end{array}$ & $\begin{array}{l}\text { trace } \\
0.0320 \\
0.0334 \\
\cdots \cdots \\
\cdots \cdots \\
\cdots \cdots \\
\cdots \cdots\end{array}$ & $\begin{array}{r}\ldots \ldots \\
\cdots \ldots \\
\cdots \ldots \\
7.6 \\
12.2 \\
\cdots \cdots \\
\cdots \cdots \\
\ldots \ldots\end{array}$ & $\begin{array}{r}2.077 \\
\mathrm{I} .993 \\
2.352 \\
\mathrm{I} .740 \\
\mathrm{I} .820 \\
\ldots \ldots . \\
\ldots \ldots \\
\ldots \ldots\end{array}$ & $\begin{array}{l}\cdots \cdots \\
\cdots \\
\cdots \\
\cdots \\
0.094 \\
0.1240 \\
0.0570 \\
0.0660 \\
0.0910\end{array}$ & $\begin{array}{l}\cdots \\
\cdots \\
\cdots \\
0.0006 \\
0.0030 \\
0.0026 \\
0.0009 \\
0.0017\end{array}$ & $\begin{array}{l}\text { trace } \\
0.0553 \\
0.0595 \\
0.0485 \\
0.0543 \\
\cdots \\
\cdots\end{array}$ \\
\hline
\end{tabular}

Plants grown in the solution containing $98 \mathrm{Na}:{ }_{2} \mathrm{Ca}$ attained the greatest dry weight and were larger than any others in the series. From this solution the greatest amount of ash constituents was

\section{TABLE II}

WHEAT PLANTS GROWN I6 DAYS IN SOLUTION CULTURES; IOO PLANTS WITH SEEDS ATTACHED

\begin{tabular}{|c|c|c|c|c|c|}
\hline \multirow{2}{*}{$\begin{array}{l}\text { Ratio of Na AND CA IN } \\
\text { SOLUTION }\end{array}$} & \multicolumn{4}{|c|}{ COMPOSITION OF IOO PLANTS } & \multirow{2}{*}{$\begin{array}{c}\text { Ratio OF NA } \\
\text { TO ASH }\end{array}$} \\
\hline & Dry weight & Ash & $\mathrm{Ca}$ & $\mathrm{Na}$ & \\
\hline 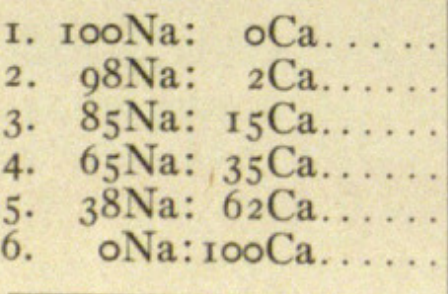 & $\begin{array}{l}2.10 \\
2.74 \\
2.37 \\
2.41 \\
2.27 \\
2.33\end{array}$ & $\begin{array}{l}0.1950 \\
0.2250 \\
0.1730 \\
0.1842 \\
0.1930 \\
0.2040\end{array}$ & $\begin{array}{l}0.006 \\
0.0102 \\
0.0106 \\
0.0132 \\
0.0204 \\
0.0226\end{array}$ & $\begin{array}{l}0.017 \\
0.022 \\
0.019 \\
0.016 \\
0.012 \\
0.008\end{array}$ & $\begin{array}{l}I: 11.5 \\
1: 10.2 \\
I: 9.1 \\
I: 11.5 \\
I: 16.1 \\
I: 25.5\end{array}$ \\
\hline
\end{tabular}

absorbed and also the greatest amount of sodium. None of the other solutions appeared to contain as favorable a ratio of sodium to calcium, although the dry weight of plants in the last 4 solutions does not vary enough to offset the experimental error. The 
$\mathrm{Na}$ :ash ratio in the first 4 sets of plants does not show any real difference. In the last 2 the relative amounts of sodium are less.

The amounts of sodium and calcium actually absorbed and retained by the plants may be of more interest to consider because they will show what the plants in the various cultures actually "fixed." The results shown in table III are taken from table II,

TABLE III

Amounts of NA AND CA ABSORBED FROM SOLUTIONS BY WHEAT PLANTS IN I6 DAYS

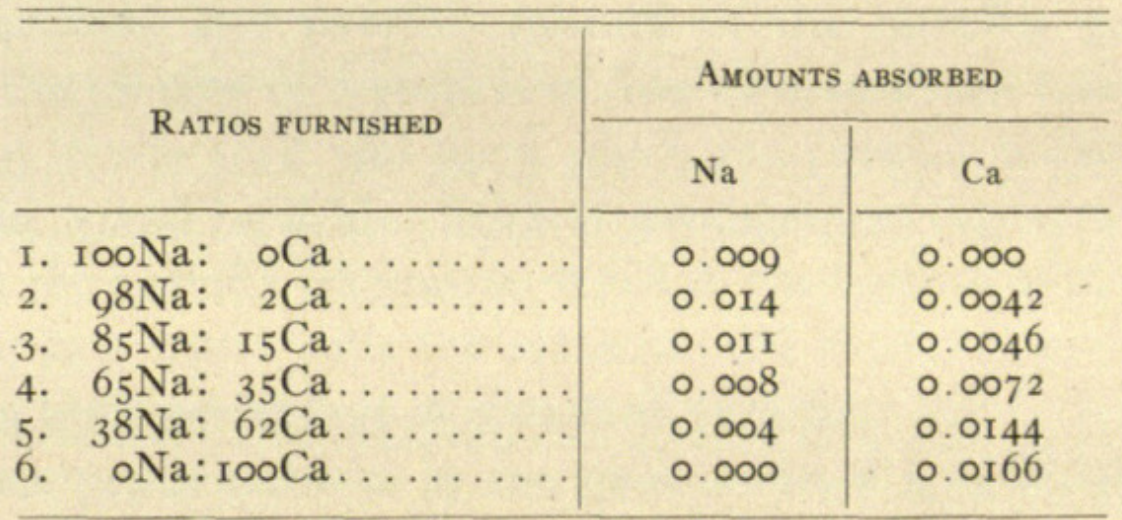

and show the amounts of sodium and calcium after deducting what was found in plants grown in solutions containing none of the element in question.

These results show that the greatest amount of sodium was absorbed from the solution containing the ratio $98 \mathrm{Na}: 2 \mathrm{Ca}$. Less sodium was absorbed from any other combination, even from pure sodium chloride. At the same time they also show no such selective absorption in the case of calcium. The amounts of calcium absorbed increase steadily as the amount in the solution increases, reaching their maximum in pure calcium chloride. There appears to be a "preferred ratio" of calcium for sodium, but none of sodium for calcium, although more cultures employing smaller amounts of sodium chloride should have been tried.

\section{Summary}

The antagonism of calcium and sodium which has been found by other workers exists also in more dilute solutions and may be shown by chemical analyses of the plants grown therein. 
Concentrations of sodium chloride which were strongly toxic to wheat seedlings were antidoted by 30 parts per million of calcium oxide.

The most successful antagonism in the concentrations employed was found when the $\mathrm{Na}: \mathrm{Ca}$ ratio was $98: 2$. At this ratio the calcium was not found to exclude sodium from the plant, but to render it harmless after entrance. The antagonism appears to be internal rather than peripheral.

University of California Citrus Experiment Station

RIVERside, Cal. 


\section{$2 \mathrm{BHL}$ Biodiversity Heritage Library}

Reed, Howard S . 1918. "Absorption of Sodium and Calcium by Wheat Seedlings." Botanical gazette 66(4), 374-380. https://doi.org/10.1086/332350.

View This Item Online: https://www.biodiversitylibrary.org/item/109341

DOI: https://doi.org/10.1086/332350

Permalink: https://www.biodiversitylibrary.org/partpdf/224073

\section{Holding Institution}

Missouri Botanical Garden, Peter H. Raven Library

\section{Sponsored by}

Missouri Botanical Garden

\section{Copyright \& Reuse}

Copyright Status: Public domain. The BHL considers that this work is no longer under copyright protection.

This document was created from content at the Biodiversity Heritage Library, the world's largest open access digital library for biodiversity literature and archives. Visit BHL at https://www.biodiversitylibrary.org. 